\title{
Harapan dan Penilaian Industri Konstruksi terhadap Ketrampilan Lulusan Teknik Sipil
}

\author{
Albani Musyafa \\ Universitas Islam Indonesia \\ Email: albani@uii.ac.id atau albani musyafa@yahoo.com
}

This research proposes to explore the quality of graduates of higher education in civil engineering in Australia. The result of the research can be used to help civil engineering education providers to apply a strategy to improve the quality of their graduates. The study uses primary data from the personal of construction industry, the data of which are analyzed statistically. This study reveals about the evaluation of the skill of civil engineering graduates by construction industry; the expectation of construction industry toward the skill which has to be mastered by graduates of civil engineering; and the gap between the evaluation and the expectation.

Keywords: construction industry, skill of graduates, quality of graduates, civil engineering.

\section{Pendahuluan}

$\mathrm{P}$ endidikan tinggi teknik dipandang sebagai suatu hal yang penting dalam kehidupan moderen karena ia menghasilkan lulusan yang berguna bagi pekembangan industri. Melalui industri ini, pendidikan tinggi teknik dapat mepengaruhi kehidupan ekonomi, sosial, budaya pada tingkat individu, masyarakat, nasional maupun global [1]. Karena perannya yang sangat penting inilah, mutu pendidikan teknik ini perlu dipantau dan ditingkatkan secara terus menerus.

Mutu pendidikan teknik mendapat perhatian khusus oleh peneliti dan orang industri sejak tahun 1990 an [2, 3]. Akhirakhir, perhatian ini bertambah dengan adanya isu-isu yang sedang berkembang berkaitan dengan perubahan-perubahan dalam industri dan profesi. Pada awal abad 21, dalam rangka meningkatkan mutu lulusannya, National Academy of Engineering mengeluarkan suatu laporan yang meminta reformasi pendidikan teknik secara besar-besaran di Amerika Serikat [4]. Sejak itu, banyak jurnal ilmiah telah diterbitkan untuk melaporkan dan mendiskusikan perkembangan dalam pendidikan teknik. Selanjutnya, UNESCO mendirikan UICEE (Unesco International Centre for Engineering Education) yang mempunyai cabang di berbagai penjuru dunia.

Dari laporan-laporan yang telah dipelajari, kajian dalam mutu pendidikan ini dapat dibagi menjadi beberapa kategori, yaitu metode pembelajaran, kurikulum dan lulusan. Sementara ini, mutu kurikulum dan 
metode pembelajaran telah didiskusikan dalam banyak laporan ilmiah, sedangkan diskusi tentang mutu lulusan jarang ditemukan. Oleh karena itu, sebuah kajian pada mutu lulusan pendidikan teknik akan bermanfaat untuk melengkapi kajian-kajian pada mutu pendidikan teknik.

Namun demikian, mengingat keberagaman karakteristik pendidikan teknik dan industri yang terkait dengannya, studi tersebut dibatasi pada jurusan teknik sipil tingkat sarjana dan industri konstruksi. Data diperoleh pada sekitar tahun 2007.

Sesuai dengan latar belakang di atas, kajian tentang harapan dan penilaian industri konstruksi terhadap ketrampilan Iulusan teknik sipil ini mempunyai rumusan masalah sebagai berikut:

1. Bagaimana mengukur tingkat ketrampilan lulusan teknik sipil yang bekerja di industri konstruksi oleh personil industri konstruksi.

2. Bagaiman mengukur harapan industri konstruksi terhadap ketrampilan lulusan teknik sipil.

Setelah tingkat ketrampilan lulusan dan harapan industri tersebut diperloleh, maka kesenjangan antar keduanya akan diidentifikasi. Identifikasi ini adalah salah satu point yang akan dilaporkan di sini. Sehingga dapat dikatakan bahawa tujuan dari laporan ini adalah membandingkan data harapan dan penilaian tersebut sehingga diperoleh informasi baru yang bermanfaat untuk membantu penyelenggara pendidikan menentukan strategi untuk peningkatan mutu lulusan teknik sipil.

\section{Kajian Pustaka}

Sesuai dengan rumusan dan tujuan lapaoran tersebut di atas, maka studi pustaka yang dilakukan diarahkan untuk mendalami dan menjabarkan konsep yang ada di dalamnya, yaitu ketrampilan lulusan teknik sipil, penilaian dan harapan industri konstruksi.

\section{Ketrampilan Lulusan}

Studi tentang ketrampilan Iulusan diarahkan untuk mengidentifikasi variabelvaiabel dari ketrampilan lulusan teknik sipil. Pada dasarnya, ketrampilan adalah bagian dari kecakapan seseorang lulusan karena suatu proses pendidikan ${ }^{1}$. Berdasarkan studi yang telah dilakukan diketahui, ketrampilan tersebut diberi sembilan variabel yang ditentukan berdasarkan atribut-atribut yang telah ditentukan oleh industry, Enginers Australia (EA), Curtin University of Technology (CUT) dan laporan-laporan ilmiah lainnya. Variabel-variabel ini akan diukur sesuai konteknya. Untuk ringkasnya, variabel ketrampilan tersebut dapat dilihat pada Table 1.

\section{Penilaian Industri Konstruksi}

Penilaian industri konstruksi dilakukan oleh personil-personil industri konstruksi yang mengetahui ketrampilan lulusan teknik sipil di tempat kerjanya. Penilaian tersebut didasarkan pada pengamatan responden yang diukur dalam lima tingkat seperti tampak dalam Table 2. Penilaian ini dilakukan untuk setiap variable yang telah ditentukan sebagaimana dicantumkan dalam Table 1. Hasil pengamatan ini akan disajikan pada Bagian 5.1.

\section{Harapan Industri Konstruksi}

Data harapan industri konstruksi diambil dari personil-personil yang juga memberikan penilaian. Oleh karena itu, agar tidak menimbulkan kerancauan dalam pemberian data, harapan industri konstruksi 
Harapan dan Penilaian Industri Konstruksi Terhadap Ketrampilan...; Albani Musyafa 